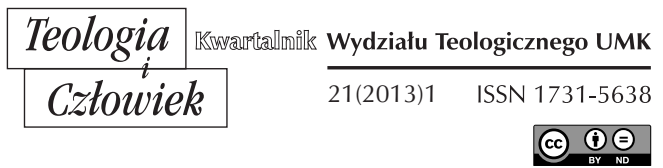

KRZYSZTOF PILARZ*

TORUŃ

\title{
SALOMON - CZłOWIEK BOŻEJ MĄDROŚCI? KILKA UWAG NA PODSTAWIE 1 KRL 1-11
}

DOI: http://dx.doi.org/10.12775/TiCz.2013.008

\section{WSTĘP}

W Piśmie Świętym, a zwłaszcza w Starym Testamencie, jego czytelnik spotyka się z ogromną rzeszą rozmaitych postaci, charakterów, ze starożytnymi opisami początków i dziejów ludzkości jako takiej, ale i z mniej lub bardziej szczegółowymi historiami pojedynczych osób. Wśród tej plejady biblijnych bohaterów są postacie mniej lub bardziej rozpoznawalne, ale trudno byłoby znaleźć, zwłaszcza w odniesieniu do tekstów wchodzących do zbioru tzw. proroków wcześniejszych (czy nawet i późniejszych, jeżeli wziąć pod uwagę zakres zainteresowania synagogalnej haftary), kogoś, kto nie znałby imion dwóch królów Zjednoczonego Królestwa: Dawida i Salomona. Szczególnie ten drugi, nawet przez osoby niezaznajomione $\mathrm{z}$ Biblią, kojarzony jest $\mathrm{z}$ archetypem władcy o wyjątkowej mądrości, dysponującym bajecznym bogactwem. Nie bez powodu J. Homerski, autor komentarza do 1-2 Krl w Biblii Poznańskiej, pisząc

* Krzysztof Pilarz - dr n. hum., pedagog i teolog, certyfikowany specjalista terapii uzależnień oraz terapeuta TSR, biegły sądowy ds. uzależnień, adiunkt w Zakładzie Pedagogiki Pastoralnej UMK w Toruniu. 
o 1 Krl 3-11 nazywa ów fragment „najpiękniejszymi kartami historii Narodu Wybranego i najchlubniejszym świadectwem mądrości i roztropności Salomona, wielkiego budowniczego pierwszej Świątyni w Jerozolimie"11. Uważne przyjrzenie się $1 \mathrm{Krl} 1-11$ pozwala stwierdzić, że zawarty w tych rozdziałach opis Salomona wcale nie jest tak jednoznaczny, jak mogłoby się to początkowo wydawać.

\section{WIARYGODNOŚĆ 1 KRL 1-11}

Pierwsze, co w tej analizie warte jest uwzględnienia, to umiejscowienie $1 \mathrm{Krl}$ 1-11 w szerszym kontekście. Nie czas i miejsce tu na przedstawienie drogi, jaką w wypracowaniu swojej teorii deuteronomistycznego dzieła historycznego przeszedł M. Noth, dokonując kompilacji i rozwinięcia wcześniejszych badaczy, m.in. J. Wellhausena, A. Alta czy W.M.L. de Wette'a, czy na ukazanie modyfikacji teorii Notha, dokonanych przez R. Smenda (wprowadzenie DtrH, DtrP, DtrN), F. M. Crossa (Dtr I, II) ${ }^{2}$ czy J. van Setersa ${ }^{3}$. Dość powiedzieć, że w zbiorze tzw. historii deuteronomicznej (obejmującym księgi: Joz, Sdz, 1-2 Sm, 1-2 Krl) zauważyć można ślady przynajmniej kilku redakcji, zarówno w okresie przed, jak i powygnaniowym ${ }^{4}$. Same Księgi Królewskie obejmują swoją

${ }^{1}$ J. Homerski, Wstęp do Ksiąg Królów, w: Pismo Święte Starego i Nowego Testamentu (tzw. Biblia Poznańska), Warszawa 2009, s. 504.

2 Por. G. Braulik, Deuteronomistyczne dzieto historyczne, w: W.R. Farmer (red. oryg.), W. Chrostowski (red. pol.), Międzynarodowy komentarz do Pisma Świętego, Warszawa 2001, s. 426-432. Por. F.M. Cross, Cannanite Myth and Hebrew Epic, Cambridge 1973, s. 274-279.

${ }^{3}$ Por. M. Cogan, Księgi Królewskie, w: P.J. Achtemeier (red.), Encyklopedia biblijna (dalej: EnB), Warszawa 1999, s. 634-637.

${ }^{4}$ Pomimo wielu dyskusji na temat szczegółowych zmian redakcyjnych oraz czasu ich dokonania wśród badaczy panuje generalnie zgodność co do traktowania zbioru jako pochodzącego od jednego autora (bądź szkoły). Por. S.W. Holloway, Kings, Book of 1-2, w: D.N. Freedman (red.), The Anchor Bible Dictionary, New York 1997 (ed. elektroniczna; w wyd. papierowym t. 4, s. 69-83); J.T. Walsh, Ch.T. Begg, Pierwsza i Druga Księga Królewska, w: R.E. Brown, J.A. Fitzmyer, R.E. Murphy (red. oryg.), W. Chrostowski (red. pol.), Katolicki komentarz biblijny, Warszawa 2004, s. 264-301 (zwł. 264n.) Por. np. K. Wojciechowska, deuteronomistyczne dzieło, w: T. Gadacz, B. Milerski (red.), Religia. Encyklopedia PWN, edycja elektroniczna, Warszawa 2003; b.n.a., Królewskie Księgi, w: tamże. W kwestii zmian redakcyjnych przeważa pogląd, że historia deuteronomistyczna była napisana pierwotnie w okresie powygnaniowym, a dopiero później uzupełniona, zmieniona przez kolejne redakcje. Por. np. A.D.H. Mayes, Historia deuteronomistyczna, w: 
treścią okres ponad czterech stuleci, tj. od końca panowania Dawida (ok. X wiek p.n.e.) do 586 p.n.e. (a konkretniej - do ułaskawienia króla Jojakina przez Ewil Merodaka). Tak szeroka cezura czasowa, w połączeniu z dużą ilością znajdujących się w 1-2 Krl informacji, była i w dalszym ciągu jest źródłem licznych spekulacji na temat ich historycznej wartości.

$\mathrm{Z}$ jednej strony znajdujące się $\mathrm{w}$ oryginalnym tekście odniesienia do nieznanych już dzieł, na które powołuje się autor (redaktor), mogą sugerować jego dbałość o jak najdokładniejsze przedstawienie ówczesnych realiów historycznych. W $1 \mathrm{Krl}$ 11,41 mamy odniesienia do „Księgi mów/ kronik Salomona" (w BHS: פסרי שלמה; BP: Księgi Dziejów Salomona; w BPaul: kroniki Salomona), w 1 Krl 14,29 czytamy o „Księdze Kronik Królów Judy" (BHS: ספר רברי הימים למלכי יהודה), w 1 Krl 14,19 dowiadujemy się o analogicznych kronikach królów Izraela (BHS: רברי הימים למלכי ישראל רפס $)^{5}$... Jak pisał J. Homerski w swoim komentarzu do 1-2 Krl, zamieszczonym w Biblii Poznańskiej,

„historyczne znaczenie tych Ksiąg, dzięki coraz nowszym odkryciom i pracom archeologicznym, wzrasta niemal z roku na rok. Poza tekstami asyro-babilońskimi ważną rolę w naświetlaniu tekstu Ksiąg Królów odgrywają ostraki z Samarii i Lakisz, stela Meszy, króla Moabu, napis z Siloe w akwedukcie Ezechiasza, a przede wszystkim wykopaliska palestyńskie. Szczegóły odkopanych miejscowości potwierdzają już to ogólnie bieg wydarzeń historycznych Ksiąg Królów, już to rzucają pewne światło na niektóre słowa, zwroty, wzmianki Autora natchnionego, których często nie brano wystarczająco $\mathrm{w}$ rachubę lub które uważano za niepewne" (BP, s. 505).

Patrząc z drugiej strony, całkiem niedawno podważono hipotezy, jakoby w Megiddo odkryto szczątki stajni Salomona (zakładając, że w ogóle były to stajnie, pochodziłyby co najwyżej z czasów Achaba), ruin odkrytych $\mathrm{w}$ latach trzydziestych XX w. w pobliżu Akaba/Elat nie uważa się już za pozostałości portu Esjon Geber, a słynne kolumny Salomona w Timna, na północ od Elat, zostały najprawdopodobniej

R.J. Coggins, J.L. Houlden (red. oryg.), W. Chrostowski (red. pol.), Stownik hermeneutyki biblijnej, Warszawa 2005, s. 253-255; Tamże, I.W. Provan, Księgi Królewskie (1-2 Krl), s. 493-495.

${ }^{5}$ Por. paragraf „Sources Identified In Kings” w: S.W. Holloway, Kings, Book of 1-2, ABD, t. 4, s. 71 . 
opuszczone już ok. XII-X w. p.n.e., a więc nie mogły być przez Salomona używane. Pomimo tego, jak twierdzi J. Warzecha, „budownictwo Salomona przedstawia się imponująco i potwierdza wiarygodność przynajmniej niektórych przekazów 1 Krl o trzecim królu zjednoczonej monarchii"6.

Czytelnikowi 1 Krl 1-11 może pojawić się uzasadnione pytanie, które dwukrotnie postawił Philippe Gruson w książce „Biblia i jej kultura”: „Kim naprawdę był Salomon?"7. Jeżeli w czasie napisania pierwszych jedenastu rozdziałów $1 \mathrm{Krl}$ było już tyle innych źródeł, z „Kroniką Dziejów Salomona” na czele, po co autor zdobył się na przepracowanie znanej już historii? I jak wyjaśnić to, że w 1 Krl 1-11 trzy rozdziały, tj. 1-2 oraz 11, będące klamrami opowieści, przedstawiają Salomona w sposób zdecydowanie różniący się od opisu zawartego w 1 Krl 3-10, co wywołuje u czytelnika ambiwalentny stosunek do Salomona? Jak to się stało, że źródła wzmiankowane w 1-2 Krl zaginęły bez śladu? ${ }^{8}$

\section{KRL 1-11 - NIEJEDNOZNACZNOŚĆ OBRAZU SALOMONA}

Julian Warzecha, syntetycznie ukazując aktualną problematykę badań dotyczących Salomona i królestwa, którym rządził, podkreśla, iż „wiarygodność przekazów o Salomonie nie wyklucza [...] pewnej stronniczości w jego przedstawianiu" ${ }^{\prime 9}$. Autor ten stwierdza, że przedstawianie Salomona w jak najlepszym świetle było efektem nie tylko sympatii

${ }^{6}$ J. Warzecha, Historia dawnego Izraela, Warszawa 2005, s. 174-177 (cyt. s. 177). Por. G.N. Knoppers, Solomon, w: D.N. Freedman, A.C. Myers, A.B. Beck (red.), Eerdmans Dictionary of the Bible, Grand Rapids, Mich. 2000, s.1235-1238 (zwł. s. 1238, gdzie znajduja się informacje nt. historycznych świadectw dotyczących budowli Salomona).

7 Por. Ph. Gruson, podrozdział „Salomon Mędrzec (972-932) (1 Krl 1-11)”, w: M. Quesnel, Ph. Gruson (red.), Biblia $i$ jej kultura. Stary Testament, Ząbki 2008, s. 209-216 (pytanie s. 214.215). Chronologia dotycząca Salomona nie jest pewna - oprócz daty 972-932 można spotkać się z datowaniem jego panowania na lata 961-922 (tak np. w P. Matthiae, M.A. Levi, A. Pellizari, S. Giorcelli, Historia powszechna, t. 2: Od prehistorii do cywilizacji na kontynentach pozaeuropejskich, Warszawa 2007, s. 475) czy ok. 965-926 (tablica chronologiczna w BPaul, s. 2954). F.E. Greenstein pisze z kolei ostrożnie o „czterdziestu środkowych latach X w. przed Chr." (tenże, Salomon, EnB, s. $1074-1076$.

${ }^{8}$ Zauważmy, że Biblia wymienia jeszcze inne dzieła na temat Salomona w 2 Krn 9,29, co powiększa liczbę zaginionych źródeł.

9 J. Warzecha, Historia, s. 174-217 (cyt. s. 178). 
do niego oraz do związanej z nim historii, ale służyło też legitymizacji jego władzy, która jednoznacznie mu się przecież nie należała, jako że prawowitym dziedzicem po Dawidzie był jego najstarszy syn, Adoniasz. Nieco dalej Warzecha, nawiązując do całego dzieła deuteronomistycznego, stwierdza: "nadal się uznaje, że jest ono pierwszą historią w Biblii i przyznaje się mu znaczny stopień wiarygodności. Mimo to jednak zauważa się coraz bardziej, że nie jest ono dziełem 'bezinteresownym'. Pisane jest w określonym czasie i dla określonych potrzeb"10. W istocie, w $1 \mathrm{Krl}$ 1-11 mamy do czynienia z przeplatającymi się dwoma nurtami, z których jeden nosi cechy pisma propagandowego, drugi - cechy literatury pisanej w okresie kryzysu. Najprościej byłoby do pisma propagandowego zaliczyć $1 \mathrm{Krl}$ 3-10, a do literatury kryzysu $1 \mathrm{Krl} \mathrm{1-2} \mathrm{i} \mathrm{11,} \mathrm{tymczasem}$ nawet $1 \mathrm{Krl}$ 3-10 wydawać się może tekstem krytycznym względem króla. Dlaczego? Za klasyczny tekst propagandowy dotyczący Salomona można uznać 2 Krn 1-9. Nie tylko nie opisuje on kontrowersyjnego sposobu zdobycia tronu przez Salomona i pomija dokonane szybko po intronizacji mordy, nie tylko nie wspomina o kryzysie królestwa i bałwochwalstwie Salomona, ale pomija także zabójstwo Uriasza i grzech z Batszebą, zaledwie lakonicznie wspomina o wybudowaniu oprócz Świątyni pałacu królewskiego, tendencyjnie przedstawia sprawę miast, które Salomon podarował Chiramowi (2 Krn 8,1-2 opisuje wręcz, że to Chiram dał swoje miasta Salomonowi). Modlitwa Salomona podczas poświęcenia Świątyni (2 Krn 6,14-42), zdecydowanie anachroniczna, oraz będąca odpowiedzią na nią teofania JHWH w 2 Krn 7,12-22 stanowią wyraźnie podkreślenie prawowitości i wybitności Salomona. Lud za jego rządów był szczęśliwy i tak bogaty, że srebro nie miało wtedy prawie żadnej wartości (por. 2 Krn 9). Opis 2 Krn nie zawiera także informacji o nakładaniu przymusowych prac na Izraelitów - według 2 Krn 2,16n dotyczyły one tylko ludności napływowej.

Wydawać by się mogło, że $1 \mathrm{Krl} \mathrm{3-10,} \mathrm{adekwatnie} \mathrm{do} 2$ Krn 1-9, przedstawiać będzie króla i jego panowanie w samych superlatywach, tak się jednak nie dzieje. Już w 1 Krl 1-2 jego sposób dojścia do władzy budzi duże wątpliwości. Najstarszy syn Dawida, Adoniasz, wydawał się naturalnym kandydatem na króla. Nawet wtedy, gdy nabył sobie rydwan oraz jeźdźców oraz oddział złożony z pięćdziesięciu ludzi, Dawid nie interweniował, chociaż Adoniasz realizował w ten sposób pierwsze prawo

10 Tamże, s. $214 n$. 
przysługujące królowi, wymienione w $1 \mathrm{Sm} 8,11$. Zdobycie tronu przez Salomona wydaje się być spiskiem zawiązanym przez Natana i Batszebę, a szerzej - przez popleczników Dawida (1 Krl 1,8). Interesujące, że to Natan sugeruje Batszebie, aby powołała się na obietnicę, którą miał jej złożyć Dawid odnośnie swojego sukcesora - czy rzeczywiście padła ona wcześniej z ust Dawida (jak sugeruje to $2 \mathrm{Krn} \mathrm{1,30),} \mathrm{czy} \mathrm{też} \mathrm{był} \mathrm{to}$ sprytny wybieg, wykorzystujący słabnące siły (w tym także i pamięć) starego człowieka? ${ }^{11}$

W 1 Krl 3-10 historia Salomona rozpoczyna się od poślubienia córki władcy Egiptu. Młody władca składa jeszcze wtedy krwawe ofiary i pali kadzidło na wyżynach. Salomon sprowadza córkę faraona do Jerozolimy zaraz po wybudowaniu swojego pałacu, który to - rzecz ciekawa - budowany był dwa razy dłużej niż sama Świątynia. Znamienne, że dziedziniec pałacu był skonstruowany podobnie jak wewnętrzny dziedziniec Świątyni i jej przedsionek (por. $1 \mathrm{Krl} \mathrm{7,12).} \mathrm{Można} \mathrm{tutaj} \mathrm{pokusić} \mathrm{się}$ o pewną analogię - Salomon sprowadza do Świątyni, Domu JHWH, Arkę Przymierza, aby odpowiednio Go uczcić, ale równocześnie sprowadza sobie obcą kobietę i wprowadza ją do swego domu, wbrew poleceniu JHWH (zob. 1 Krl 11,1-10). Salomon w bliżej niewyjaśnionych okolicznościach, oddaje (sprzedaje?) Chiramowi dwadzieścia miast galilejskich, co stoi w sprzeczności z panującym przekonaniem, iż ziemia należy do Boga, a król jest tylko jej zarządcą ${ }^{12}$.

${ }^{11}$ Przyjmując, że niedołężny król Dawid mógł zostać zmanipulowany, można zwrócić uwagę na podobieństwo pomiędzy imieniem umiłowanego syna Dawida, Absaloma (אבישלום), z Salomonem (שלמה). Czy możliwe, że Natan i Batszeba, odnosząc się do rzekomych obietnic króla, mogli wykorzystać jego ewentualne problemy z pamięcią, przywołując Dawidowi obraz jego najdroższego potomka? To oczywiście tylko spekulacje, niemniej jednak niepozbawione uzasadniających je przesłanek. Absalom znany był z tego, że zjednywał sobie serca Izraelitów poprzez siadywanie w bramie i obietnice sprawiedliwego rozstrzygania spraw sądowych; Por. jego słowa w 2 Sm 15,4: „Któż ustanowi mnie sędzią w tym kraju? Przychodziłby do mnie każdy, kto miałby sprawę sądową, a ja bym rozsądzał i wydawałbym sprawiedliwy wyrok" (BP). Z drugiej strony, do zachowania Absaloma bliżej jest jednak Adoniaszowi, który nawet z wyglądu przypominał swojego starszego brata (1 Krl 1,5-6), poza tym po rozmowach z Natanem i Batszebą reakcja Dawida jest opisana jako bardzo konkretna $(1 \mathrm{Krl} \mathrm{1,28}$ nn.), co osłabia siłę tej argumentacji - chyba że wzięlibyśmy pod uwagę ewentualność późniejszego zredagowania źródła w celu uzasadnienia przejęcia tronu przez Salomona. Tak czy inaczej, kwestia jest otwarta.

${ }^{12}$ Por. G. Becquet, Ziemia, w: X. Leon-Dufour, Stownik teologii biblijnej, Poznań 1994, s. 1129-1135. 


\section{SALOMON A USTAWY KRÓLEWSKIE Z PWT 17,14-20}

Szczególnie druzgocąco wygląda opis panowania Salomona w zestawieniu z prawem królewskim zawartym w Pwt 17,14-20. Władca nie mógł mnożyć sobie koni ani prowadzić ludzi z powrotem do Egiptu, aby przymnożyć koni $(17,16)$, gdy tymczasem Salomon dysponował ogromną ich liczbą - miał „,cztery tysiące stanowisk dla koni dla swoich rydwanów i dwanaście tysięcy wierzchowców" (1 Krl 5,6, BP), które pochodziły z Egiptu oraz z Koa, jak czytamy w 2 Krn 1,16-1713. Władca nie mógł powiększać sobie liczby żon oraz mnożyć bogactw, a oba z tych przepisów Salomon łamie tak, jak nikt inny przed i po nim (zob. np. $1 \mathrm{Krl}$ 10,14-27; 11,1nn.) ${ }^{14}$. Gdyby faktycznie do prac przymusowych zatrudniał ludność napływową, jak czytamy w $1 \mathrm{Krl}$ 9,15-23, nie miałby sensu incydent opisany trzy rozdziały dalej, kiedy to zgromadzenie Izraela skarży się na jarzmo nałożone przez Salomona, co skutkuje podziałem królestwa $(12,1-17)$. Opis dyskusji Roboama z delegatami daje przy tym jasno do zrozumienia, że dobrobyt opisany we wcześniejszych rozdziałach $1 \mathrm{Krl}$ wcale nie wyglądał tak idyllicznie. W 1-2 Krl nawet pobożność Salomona jest poddana krytyce, co uwidacznia opis reformy Jozjasza ${ }^{15}$. Nawet 1-2 Krn, przedstawiane jako bardziej prosalomonowe niż 1-2 Krl, pośrednio uwypuklają niedoskonałe sprawowanie kultu przez Salomona, kiedy to $\mathrm{w}$ opisie obchodzenia święta Paschy przez Jozjasza dowiadujemy się, iż „żadne Święto Paschy nie było obchodzone w Izraelu tak jak to, od czasów Samuela proroka; żaden też spośród królów Izraela nie obchodził w taki sposób Święta Paschy, jak je obchodził Jozjasz" (2 Krn $35,18, \mathrm{BP})$.

${ }^{13}$ Por. 1 Krl 10,28-29, gdzie wymienione są wprawdzie inne miejsca: Mucri (znajdujące się na północ od gór Taurus w Kapadocji) i Kuwe (miejscowość we wschodniej części Cylicji; Vg ma tu Coa, co pokrywa się z 2 Krn 1,16), ale jest też mowa o cenach egipskich rydwanów, którymi handlował Salomon.

${ }^{14}$ Trzeba tu jednak podkreślić, że wielkie bogactwo i sława Salomona są darami JHWH, który ofiarował je Salomonowi w uznaniu za jego prośbę o „serce pojętne" do rozpoznawania dobra i zła w celu sprawowania sądów (1 Krl 3,4-15).

${ }^{15}$ Por. zwł. 2 Krl 23,25, gdzie czytamy o Jozjaszu: „Nie było przed nim takiego jak on króla, który by wrócił do Jahwe całym swoim sercem, całą swą duszą, z całych swych sił, według całego prawa Mojżeszowego i po nim nie zjawił się jemu podobny" (BP). 


\section{1-2 KRL - NEGATYWNY OBRAZ SALOMONA?}

W świetle tego, co zostało już powiedziane, warto wrócić do $1 \mathrm{Krl}$ $1-2$, jako że te dwa rozdziały w ostatecznej redakcji wyznaczają zasadniczy sposób interpretacji dalszej części dzieła. Wydaje się dużym uproszczeniem traktowanie tych rozdziałów jako przedstawiających Salomona w złym świetle. Chociaż przyporządkowanie ich do literatury kryzysu znajduje swoje głębokie uzasadnienie, to i cechy propagandy prosalomonowej także są tu widoczne. Wobec spisku zawiązanego przez Natana oraz niepewną losu własnego oraz syna Batszebę ${ }^{16}$, Salomon wykazuje się miłosierdziem, a zarazem konsekwencją i stanowczością w przejmowaniu władzy. Daruje życie Adoniaszowi, mówiąc, że ,jeśli okaże się człowiekiem uczciwym, włos mu z głowy nie spadnie, jeśli natomiast będzie coś knuł, umrze" (1 Krl 1,52, BPaul). Pomimo polecenia Dawida dotyczącego uśmiercenia Szimeiego Salomon także i jemu daje szansę, którą Szimei lekceważy (1 Krl 2,36-46). Nowy król ma także wzgląd na dawnego towarzysza Dawida, kapłana Abiatara, darując mu życie, gdyż nosił on arkę JHWH oraz dzielił losy poprzedniego władcy. Zdejmując Abiatara z urzędu arcykapłana Salomon stał się wykonawcą woli JHWH odnośnie domu Helego (1 Krl 2,26n). Jednocześnie okazuje szacunek ojcu poprzez przykładne rozprawienie się z Joabem, który w imię własnych ambicji pozbawił życia Abnera i Amasę (1 Krl 2,28-34). Niejako „przy okazji" tych wydarzeń Salomon wprowadza na kluczowe stanowiska w królestwie swoich ludzi, kontrolując tym samym władzę religijną (Sadok w miejsce Abiatara) i wojskową (Benajasz w miejsce Joaba). W 1-2 Krl Salomon jawi się więc jako władca sprawiedliwy i mądry - na jego mądrość (חפ) zwraca uwagę umierający Dawid w swoim testamencie (2 Krl 2,1-9), zachęcając przy tym Salomona, aby „okazał się mocnym i był mężczyzną" $(2,2)$.

\section{KONTROWERSJE WOKÓł MĄDROŚCI SALOMONA}

Zagadnienie mądrości Salomona może wydawać się kontrowersyjne. Owszem, z czysto pragmatycznego punktu widzenia wydaje się

${ }^{16}$ Nie dość, że jej przyszłość w przypadku koronowania Adoniasza była zagrożona, to jeszcze król miał w swym łożu młodszą, piękniejszą kobietę, Abiszag, co dodatkowo spychało Batszebę na boczny tor. Por. J.T. Walsh, Ch.T. Begg, Pierwsza i Druga Księga Królewska, s. 268. 
on być niemalże idealnym królem - błyskotliwie wykorzystuje pierwszy okres rządzenia, aby pozbyć się przeciwników i zapewnić wsparcie ze strony zwolenników; jego prace budowlane, zwłaszcza Świątynia i pałac, zapierają dech w piersiach, podobnie jak całe jego bogactwo. Liczne małżeństwa, jak też mnogie kontakty z bliższymi i dalszymi królestwami, są wyrazem politycznej mądrości i rozwagi. Salomon otrzymał od JHWH "serce pojętne" (לב שמן), dosłownie "słyszące/słuchające", „rozumiejące $^{\prime \prime 17}$, które miało mu służyć do sądzenia, przy czym użyte w oryginale słowo שפט ma szerszy zakres znaczeniowy, obejmując czynności związane z szeroko rozumianym rządzeniem ${ }^{18}$. JHWH daje Salomonowi ונבן ,serce mądre i rozumne" (1 Krl 3,12, BHS i BP), co stanowi dar większy nawet, niż prosił młody król ${ }^{19}$. Jednocześnie do daru tego jest dołączona obietnica obdarowania Salomona długim życiem, ale jest ona obwarowana warunkiem chodzenia drogami Bożymi, przestrzeganiem Jego praw i nakazów (1 Krl 3,14). Tymczasem Salomon, osiągając dzięki opiece Boga wielkość nieosiągalną dla innych królów, gubi się w we własnej chwale i politycznych zależnościach, co ostatecznie doprowadza go do odejścia od JHWH i służenia fałszywym bogom. Czy naprawdę wierzył $\mathrm{w}$ ich istnienie i ich czcił, czy też uczestniczył $\mathrm{w}$ kulcie tylko ze względów politycznych? A może historyczny Salomon, stykając się $\mathrm{z}$ innymi kulturami i religiami, uległ ich wpływom, gdyż wydawały mu się bardziej atrakcyjne od rodzimej religii?

W swojej znakomitej monografii dotyczącej postaci Salomona P.A. Torjano twierdzi, powołując się na $1 \mathrm{Krl}$ 5,9-14, że wielka mądrość króla nie miała zakorzenienia $\mathrm{w}$ sprawiedliwości. Teza ta znajduje potwierdzenie nie tylko w samym tekście BHS, lecz także w LXX, w której to

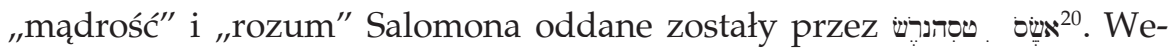
dług Torjano terminologia LXX wpłynęła na późniejsze zainteresowanie Salomonem jako mędrcem dysponującym wiedzą ezoteryczną, jako że , הלבאראפ, oznaczać może nie tylko przysłowie, ale i koniunkcję astrono-

${ }_{17}$ Por. R.L. Harris, G.L. Archer Jr., B.K. Waltke, The Theological Wordbook of the Old Testament, Chicago 1980 (dalej: TWOT), art. 1071 i 2412; L. Koehler, W. Baumgartner, The Hebrew and Aramaic Lexicon of the Old Testament, CD-ROM Edition, Leiden 2000 (dalej: HALOT), art. 4509 i 9751.

18 Por. TWOT, art. 2443; HALOT, art. 9864

${ }^{19}$ Por. Wj 36,1, w którym to mądrzy (חכ) mężczyźni charakteryzują się tym, że otrzymali od JHWH mądrość (תכמה) i zrozumienie (תבחה).

${ }^{20}$ Por. P.A. Torjano, Solomon the Esoretic King. From King to Magus, Development of a Tradition, Leiden-Boston-Köln 2002, s. 32. 
miczną ${ }^{21}$, natomiast grecki termin oznaczający w LXX pieśń (הֶרשֵֶׁ) jest skorelowany z epwdh,, co oddać można poprzez „urok” czy „zaklęcie”22. Niezależnie od tej argumentacji, znajdującej swoje uzasadnienie także u Józefa Flawiusza ${ }^{23}$, czytelnik 1 Krl 5,9-14 nie może się nie zgodzić, iż mądrość Salomona jest w tym fragmencie przedstawiona w kategorii, którą obecnie nazwalibyśmy naukową i że rzeczywiście w przywoływanym fragmencie nie odnosi się ona do Prawa JHWH, jakkolwiek od Boga pochodzi. Przytoczony już cytat z 2 Krl 23,21,22, mówiący o tym, że takiej Paschy, jaką urządził Jozjasz, nie obchodzono od dni Sędziów i przez wszystkie dni królów Izraela i Judy, tylko ten fakt podkreśla.

Model mądrości filozoficznej, ezoterycznej, często spotyka się z krytyką w manuskryptach qumrańskich. Dokumentem, w którym szczególnie wyraźnie to ukazano, jest tzw. „Księga Tajemnic”, zwłaszcza 4Q300, w którym czytamy o „magach, nauczycielach przestępstwa, mówiących przypowieść i odpowiadających na zagadkę szybciej, niż się ją wypowie" 24 ; magowie ci, nie znając sekretu stawania się (רז נהיה) oraz wizji (prawdopodobnie wizji rozważań, ywghh !wzx, wzmiankowanej chociażby w 4Q417 frag. 2 kol. 1,16-18), nie są w stanie pojąć „korzenia mądrości". Przestępstwo i niegodziwość są we wzmiankowanym dokumencie przeciwstawione sprawiedliwości, co dodatkowo wzmacnia jego przekaz $^{25}$.

${ }^{21}$ Tamże, s. 32.

${ }^{22}$ Tamże, s. 32n.

${ }^{23}$ Por. Józef Flawiusz, Dawne dzieje Izraela, VIII.II.5 (w przekł. Z. Kubiaka i J. Radożyckiego): „Nie było takiego zjawiska w przyrodzie, którego by nie znał albo nad którym nie pochyliłby się badawczo: wszystkie rzeczy badał filozoficznie i wykazywał najgruntowniejszą wiedzę o szczególnych właściwościach każdej z nich. Bóg obdarzył go również znajomością sztuki stosowanej przeciwko demonom w celu wspomagania i leczenia ludzi. Układał więc Salomon zaklęcia przynoszące ulgę w chorobach i zostawił po sobie formuły egzorcyzmów, za pomocą których ludzie opętani przez demony mogą je wygnać tak, że nie wrócą". Następnie znajduje się dokładniejszy opis takiego egzorcyzmu, podczas którego wymieniane jest imię Salomona. 11Q11 kol. 2, pomimo złego stanu zachowania, wydaje się nawiązywać do słów Salomona, chroniących przed demonami, co może być dowodem na wczesne powstanie takiej tradycji.

${ }^{24}$ Por. 4Q300 frag. 1 kol.2. Szczegółowo zagadnienie to omówione zostało w książce: K. Pilarz, Wychowanie we wspólnocie z Qumran. Studium analityczno-krytyczne, Kraków 2013 (w druku).

${ }^{25}$ Por. 4Q300 frag. 3,4b-6. 


\section{ZAKOŃCZENIE}

Podsumowując, opis Salomona w $1 \mathrm{Krl}$ 1-11 jest dużo bardziej niejednoznaczny, niż wydawać by się to mogło przy pobieżnej lekturze tego tekstu. Interpretacja, jakoby fragment ten pisany był przez redaktora deuteronomistycznego "ku pokrzepieniu serc”, wydaje się nie do utrzymania. Zbyt wiele jest w opisie mniej lub bardziej subtelnych aluzji, a nawet podanych wprost opisów sprzeniewierzenia się króla wobec Prawa JHWH. Wyjątkowo problematyczna jest kwestia czasu powstania tekstu, zwłaszcza w zestawieniu z tzw. „prawami królewskimi” z Pwt 17,14-20, jednak nawet założenie, że Pwt zredagowano po $1 \mathrm{Krl} \mathrm{1-11,}$ odnosząc się bezpośrednio do opisu panowania Salomona, nie wpływa znacząco na rozwianie wątpliwości dotyczących historii powstania obecnej wersji tekstu.

Niezależnie od tych trudności zasadniczy przekaz tekstu na "tu i teraz" zawiera jednoznaczne ostrzeżenie. Bóg może dawać człowiekowi rozliczne dary, jednak człowiek nimi obdarzony często doświadczyć może pokusy pochłonięcia przez nie - przez władzę, sławę, budowanie własnej chwały w oczach swoich i ludzi. W takim ujęciu nawet poświęcenie życia nauce może doprowadzić do upadku, jeżeli nie będzie się żyło tym, co większe od Salomona (por. Mt 12,42), a co wobec świata wydawać się może nie wyrazem mądrości, lecz głupstwem i zgorszeniem. Salomon, pomimo swej wielkości, przeminął jak trwa, stąd też ciągle aktualne pozostają słowa św. Pawła:

Gdzie jest mądry? Gdzie uczony? Gdzie ten, co wnika w sprawy świata? Czyż Bóg nie uczynił głupstwem mądrości świata? Skoro bowiem świat przeniknięty mądrością Bożą nie poznał Boga za pomocą tej mądrości, spodobało się Bogu zbawić tych, którzy wierzą, przez głupstwo głoszenia nauki. I tak, Żydzi żądają znaków, a Grecy szukają mądrości, my głosimy Chrystusa ukrzyżowanego. On jest dla Żydów powodem upadku, a dla pogan głupstwem, jednakże dla powołanych, tak Żydów, jak i Greków, jest Chrystusem - mocą i mądrością Bożą. Bo to, co głupie u Boga, mądrzejsze jest od ludzi, a co uchodzi za słabe u Boga, mocniejsze jest od ludzi (1 Kor 1,20-25; BPaul). 
Streszczenie. Salomon - człowiek Bożej mądrości? Kilka uwag na podstawie 1 Kri 1-11. W artykule przedstawiono kilka najbardziej wyraźnych wątpliwości odnośnie do niejednoznacznego przedstawienia postaci króla Salomona w 1 Kri 1-11. Jako cel postawiono skupienie się na jego powszechnie przyjmowanym obrazie jako człowieka o wielkiej mądrości i przeanalizowanie tej koncepcji przede wszystkim na podstawie zaprezentowanego fragmentu Biblii. Studium postaci Salomona stanowi doskonały przykład na to, jak wielkie znaczenie ma posługiwanie się mądrością z uwzględnieniem jej Stwórcy i Jego woli. Z tego względu tekst 1 Kri 1-11 ciągle pozostaje aktualny i w dalszym ciągu może być postrzegany jako rozbudowany tekst dydaktyczny na temat priorytetów w ludzkim dążeniu do samorealizacji.

Słowa kluczowe: Salomon; mądrość; Księga Królewska.

Abstract. Solomon - a man of God's wisdom? Some thoughts concerning 1 Kgs 1-11. The article aims to present some of the most significant concerns regarding ambiguous presentation of King Solomon in $1 \mathrm{Kgs} 1-11$. An emphasis is made here on a widely recognised image of Solomon's as a person of great wisdom. This conception is primarily analysed on the basis of the abovementioned passage of the Bible. Study of Solomon's character is an excellent example of how important it is to take into account God's person and His will when using one's wisdom. For this reason, the $1 \mathrm{Kgs} \mathrm{1-11}$ is still valid and can be viewed as an extensive didactic text on the significance of priorities in the human quest for self -fulfilment.

Keywords: Solomon; wisdom; Book of Kings. 